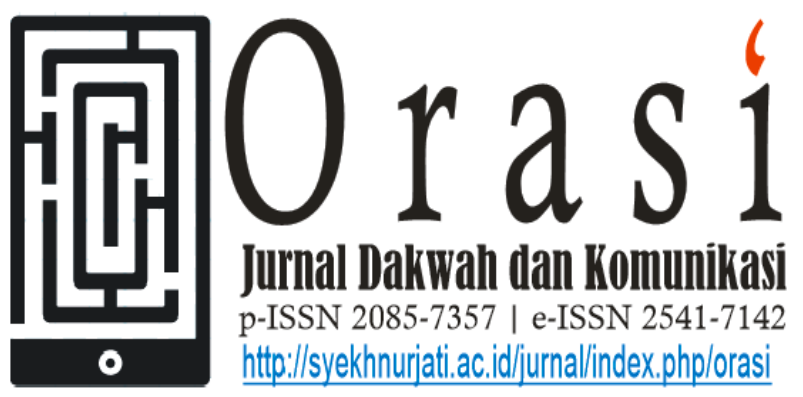

Volume 12 No. 2 Desember 2021

\title{
EKSISTENSI LDNU YOGYAKARTA DI MASA PANDEMI: STUDI POLA PERGESERAN DAKWAH
}

\author{
THE EXSISTENCE OF LDNU YOGYAKARTA \\ IN THE PANDEMIC ERA: \\ A STUDY OF SHIFTED PREACHING PATTERNS \\ Zahrotus Sa'idah1,a) dan Achmad Khusnul Khitam²,b) \\ ${ }^{1}$ Prodi Ilmu Komunikasi, Universitas Amikom Yogyakarta \\ ${ }^{2}$ Prodi Bahasa Arab, STAI Sunan Pandanaran Yogyakarta \\ a)e-mail: zahramiftah@amikom.ac.id \\ b)e-mail:khitammaliki@gmail.com
}

\begin{abstract}
ABSTRAK
Lembaga Dakwah Nahdhotul Ulama Yogyakarta merupakan organisasi yang terdiri dari dai-dai muda yang ada di Yogyakarta. Organisasi ini merupakan bagian dari salah satu organisasi Islam terbesar di Indonesia, yakni Nahdhotul Ulama. Organisasi ini berfungsi sebagai wadah bagi dai-dai muda untuk hadir secara aktif di tengah masyarakat melalui program dakwah, baik yang terjadwal maupun yang tidak terjadwal, misalnya kegiatan pemberdayaan masyarakat melalui kajian rutinan. Namun, sejak pandemi Covid-19 masuk di Indonesia, masyarakat dituntut untuk melakukan hamper seluruh kegiatan seperti belajar, bekerja, beribadah serta aktivitas lainnya di rumah, termasuk tentu saja aktivitas dakwah. Hal tersebut dilakukan guna memutus mata rantai penyebaran virus. Untuk itulah LDNU Yogyakarta kemudian melakukan berbagai adaptasi kegiatan terutama yang berkaitan dengan kontak fisik ke dalam kegiatan online. Penelitian ini menggunakan metode kualitatif dengan teknik deskriptif analitik dengan harapan penelitian ini dapat mendeskripsikan serta mempetakan problematika perubahan pola dakwah LDNU Yogyakarta demi tetap eksis di tengah masa pandemi covid-19. Dari penelitian ini ditemukan bahwa selama masa pandemi, LDNU telah beradaptasi dengan situasi yang terjadi dengan melakukan beberapa pergeseran metode dan pola dakwah, dari pola dakwah yang sebelumnya bersifat konvensional, yakni dengan "off-line preaching" ke dakwah yang lebih bersifat virtual, atau "online preaching". Di antara program dakwah tersebut adalah ngaji online, siaran on-air by phone, dan masih banyak lagi.
\end{abstract}


Kata Kunci: Dakwah, Pandemi, Media

\begin{abstract}
Lembaga Dakwah Nahdhatul Ulama (LDNU) Yogyakarta is one of the biggest religious organizations in Indonesia affiliated to Nahdhatul Ulama. This organization accomodates many young da'i who actively give da'wah (preach) to the Islamic communities, either in scheduled or accidental programs, such as religious gatherings in order to develop a society. However, since the Covid-19 Pandemic emerged in the country, in order to stop the spread, people have been demanded to do almost everything within their houses, such as study, work, pray, and other daily activities. Amid these circumstances, LDNU Yogyakarta attempts to change their programs, from physical based (off air) programs to online programs. This study used a qualitative method with descriptive analysis to describe as well as map the problems of the shifted preaching patterns in order to cope with the Covid-19 pandemic. From this research, it is found that LDNU has adapted to this pandemic situation by shifting some preaching patterns as well as methods, from conventional preaching i.e. 'off-line preaching' to virtual preaching or 'online preaching'. Some of those shifted programs are Ngaji Online, online broadcasting via phone, and many others.
\end{abstract}

Keywords: Da'wah, Preaching, Pandemic, Media.

\section{Pendahuluan}

Awal tahun 2020, Indonesia dihadapkan dengan munculnya virus covid-19 yang penyebarannya terjadi secara masif di berbagai wilayah. Adanya pandemi ini secara implisit memberikan dampak besar terhadap keberlangsungan hidup masyarakat, sebab demi memutus rantai penyebaran virus tersebut, pemerintah menganjurkan masyarakat untuk bekerja, belajar dan beribadah di rumah. Selain anjuran tersebut, pemerintah juga menerapkan berbagai kebijakan, misalnya penerapan social distancing, physical distancing, isolasi mandiri, PSBB (Pembatasan Sosial Bersekala Besar) dan yang terakhir adalah penerapan new normal (liputan6.com).

Kebijakan pemerintah dalam memutus penyebaran virus covid-19 menimbulkan banyak pertentangan dari masyarakat, mengingat masyarakat Indonesia dikenal dengan budaya berkumpul, baik yang bersifat sosial, seperti budaya "gotong-royong" maupun yang bersifat keagamaan, seperti tradisi "tahlilan", "yasinan", dan berbagai kegiatan spiritual lainnya yang sifatnya mengumpulkan masa. Oleh sebab itu, kebijakan-kebijakan pemerintah tersebut dinilai tidak sesuai dengan tradisi yang selama ini melekat serta mengakar di Indonesia, sebab secara konseptual, seluruh istilah yang dikenalkan oleh pemerintah tersebut -salah satunya social distancing- mengharuskan masyarakat untuk mematuhi seperangkat protokol kesehatan serta menjaga jarak atau tidak berkerumun. Hasilnya, dengan penetapan protokol tersebut secara kontinue memberikan efek yang signifikan di berbagai sektor di Indonesia, mulai dari sektor ekonomi, sosial, budaya, pendidikan, dan keagamaan (kompas.com). 
Di sektor keagamaan sendiri, Indonesia memiliki banyak organisasi keagamaan yang masing-masing dari organisasi tersebut memiliki berbagai macam program dan tradisi yang telah dijalankan selama bertahun-tahun. Sebut saja tradisi sholat berjamaah dalam ajaran Islam, kebaktian hari minggu dalam ajaran Kristen, maupun kegiatan spiritual lainnya. Selama masa pandemi ini, kegiatan-kegiatan tersebut ditiadakan untuk sementara waktu sampai waktu yang tidak dapat ditentukan. Begitu juga dengan kondisi di Yogyakarta. Gubenur DI Yogyakarta, Hamangkubuwono X beserta para jajaran pemerintahan daerah tengah menyiapkan tatanan normal baru (new normal) yang nanti akan diaplikasikan ke berbagai sektor jika kondisi sudah memungkinkan, salah satunya adalah sektor sosial keagamaan. (jogja.suara.com).

Satu dari sekian lembaga keagamaan yang selama ini aktif dalam aktivitas dakwah di Indonesia adalah LDNU (Lembaga Dakwah Nahdhatul Ulama) yang tersebar di berbagai wilayah di Indonesia, termasuk Yogyakarta. LDNU Yogyakarta sendiri termasuk satu dari sekian banyak organisasi keagamaan yang merasakan dampak dari kebijakan tersebut.

Perlu diketahui bahwa LDNU Yogyakarta merupakan organisasi Islam terbesar di Yogyakarta di bawah naungan Nahdhatul Ulama. Organisasi ini sendiri merupakan organisasi yang bertujuan untuk memfasilitasi sekaligus menjadi wadah bagi dai-dai muda yang ada di Yogyakarta. Adapun kegiatannya meliputi pengajian rutinan, fasilitator keagamaan, dakwah di berbagai daerah Yogyakarta dan lain-lain. Selama ini kegiatan-kegiatan tersebut dilakukan dengan menggunakan metode konvensional, yakni penerjunan para dai muda di bawah naungan LDNU Yogyakarta langsung ke lapangan.

Akan tetapi, semenjak diberlakukan kebijakan baru terkait pemutusan penyebaran virus Covid-19, skema kegiatan LDNU Yogyakarta mengalami pembaharuan dan tentunya hal tersebut menjadi masalah baru bagi LDNU sendiri terutama mengenai eksistensi LDNU sebagai lembaga dakwah. Satu dari berbagai hal yang dilakukan LDNU dalam hal ini adalah dengan memaksimalkan penggunaan media daring. Meski demikian, perubahan pola tersebut akan terus dievalusi sepanjang pandemi ini berlangsung. Namun, perlu diingat bahwa perubahan dari pola lama menuju pola baru bukanlah hal yang mudah, baik bagi LDNU Yogyakarta, para dai, maupun para audien (masyarakat). Banyak problem serta tantangan yang harus dihadapi sekaligus diselesaikan oleh LDNU Yogyakarta agar program mereka tetap eksis sekaligus memberikan kontribusi yang signifikan bagi masyarakat Muslim di masa pandemi.

Dengan landasan tersebut, peneliti berupaya mengobservasi lebih dalam terkait pola perubahan dakwah LDNU Yogyakarta melalui pertanyyaan bagaimana bentuk eksistensi LDNU Yogyakarta di masa pandemi covid-19. Dengan merujuk pada pertanyaan tersebut, maka tujuan dari penelian ini adalah untuk mendeskripsikan dan menjelaskan lebih dalam lagi terkait bentuk eksistensi LDNU Yogyakarta di masa pandemi covid-19. 
Hasil dari penelitian ini diharapkan dapat memberikan kontribusi atau manfaat, baik secara teoritis maupun praktis. Secara teoritis, penelitian ini diharapkan dapat memberikan khazanah keilmuan baru bagi peneliti yang ingin mengkaji terkait komunikasi penyiaran Islam di masa pandemi Covid-19, sedangkan secara praktis, penelitian ini diharapkan menjadi bahan referensi, baik bagi LDNU Yogyakarta maupun lembaga keagamaan lainnya agar tetap eksis dan mampu memberikan manfaat bagi masyarakat Muslim di tengah pandemi Covid-19. Mengingat pandemi Covid-19 ini merupakan hal baru yang terjadi di Indonesia, tentu kajian terkait eksistensi lembaga dakwah di masa pandemi Covid-19 dinilai penting sebab adanya pandemi ini secara tidak langsung telah merubah kebiasaan atau tradisi sebelumnya sedangkan tidak semua masyarakat di Indonesia siap dengan perubahan tersebut.

Selanjutnya, untuk mempermudah dalam proses pendeskripsian data, peneliti menggunakan beberapa referensi pendukung yang memiliki relevansi dengan penelitian ini, misalnya penelitian Revina Septhiani (2018) dengan judul "Strategi Badan Musyawarah Organisasi Islam Wanita Indonesia (BMOIWI) dalam Pembinaan Akhlak Muslimah di Masjid Istiqlal" (Septhiani, 2018), Muniaty Sirajuddin (2014) dengan judul "Pengembangan Strategi Dakwah Melalui Media Internet (Peluang dan Tantangan) (Murniaty, 2014), Pardianto (2013) dengan judul "Meneguhkan Dakwah Melalui New Media" (Perdianto, 2013). Nur Rahmad (2018) dengan judul "Rekonstruksi
Dakwahtainmen Sebagai Media Dakwah" (Rahmad, 2018).

\section{Metodologi Penelitian}

Penelitian ini menggunakan metode kualitatif dengan dua pendekatan, yaitu sosiologi komunikasi dan teknologi komunikasi. Dua pendekatan tersebut digunakan agar mempermudah peneliti dalam mengamati pola perubahan dakwah yang dilakukan LDNU Yogyakarta selama pandemi berlangsung sekaligus bentuk perubahan itu sendiri, terutama dalam penggunaan media teknologi. Untuk itu, dalam proses pengumpulan data, peneliti menggunakan metode observasi di lingkungan LDNU Yogyakarta serta mengumpulkan beberapa arsip pendukung yang dimiliki oleh LDNU Yogyakarta yakni dengan menggunakan teknik dokumentasi.

Teknik dokumentasi sendiri adalah teknik pengumpulan data yang dilakukan guna menghasilkan catatan-catatan penting yang memiliki keterkaitan satu sama lain dengan objek yang diteliti (Barowi, 2008, hal.158).Selanjutnya adalah proses analisis yang kemudian dideskripsikan secara terstruktur atau sistematis, dengan menggunakan referensi pendukung guna mempermudah serta memaksimalkan dalam proses pengelolahan data. Tahapan selanjutnya yakni uji keabsahan. Pada penelitian ini, peneliti menggunakan teknik triangulasi, yakni dengan menggunakan validitasi data melalui pengecekan data dan penggabungan data-data dari sumber yang relevan serta berbeda-beda (Sugiono, 2012). Namun demikian, mengingat 
pada saat ini Indonesia masih mengalami pandemi covid-19, untuk itu demi mempermudah proses pengumpulan data maka penelitian ini menggunakan media daring, baik melalui teleconference atau chatting yang dapat mempermudah proses wawancara terhadap narasumber pendukung.

\section{Hasil dan Pembahasan}

\subsection{Dakwah di Tengah Pandemi Covid-19}

Nahdlatul Ulama atau yang disingkat NU merupakan organisasi Islam terbesar di Indonesia. Organisasi ini memfokuskan diri pada bidang keagamaan, pendidikan, ekonomi dan sosial. Adapun keberadaannya NU sendiri adalah untuk membumikan dan menegakkan ajaran-ajaran Islam menurut paham Ahlusunna Waljama'ah di tengah kehidupan sosial beragama masyarakat di Indonesia. Untuk itu berbagai upaya dilakukan guna mengefektifkan misi tersebut yakni dengan berbagai program keagamaan, salah satunya adalah pendirian Lembaga Dakwah Nahdlatul Ulama (LDNU).

LDNU sendiri berdiri dengan tujuan sebagai media dakwah NU serta sebagai wadah bagi akademisi, praktisi, konsultan serta aktivis yang tergerak menyuarakan ajaran Ahlusunna Waljama'ah. Oleh karena itu pendirian LDNU tersebar di berbagai wilayah di Indonesia dan salah satunya ada di Yogyakarta. Sama halnya dengan wilayah lainnya, LDNU Yogyakarta memiliki beberapa program sebut saja, syiar agama melalui siara radio dalam program Spirit of Islam (RRI Pro 2), Religi Pagi (RRI Pro 1), dan dialog keagamaan.Selain itu, LDNU Yogyakarta juga bekerjasama dengan Tribun Jogja dalam syiar dakwah melalui penulisan artikel di kolom 'Cahaya Jumat'. Adapun penulisan tersebut dikhususkan untuk para dai yang tergabung dalam LDNU Yogyakarta dan tentunya dai yang ingin berkonstribusi dalam berdakwah melalui media cetak. Tidak hanya itu saja, LDNU Yogyakarta juga bekerjasama dengan Majalah Bangkit dalam mensosialisasikan kegiatan-kegiatan LDNU Yogyakarta.

$$
\text { Akan tetapi, awal tahun } 2020
$$

kegiatan-kegiatan LDNU Yogyakarta mengalami pembaharuan. Hal ini dikarenakan adanya pandemi covid-19 yang penyebaran virusnya semakin massif. Sehingga, segala kegiatan yang berhubungan dengan kegiatan tatap muka telah ditiadakan dan hal tersebut merupakan bagian dari himbauan pemerintah, yakni terkait larangan adanya kerumunan. Dengan demikian kegiatan yang sebelumnya bertatap muka dialihkan ke sistem daring.

Beberapa dekade ini, penggunaan sistem dakwah daring memang cukup popular di kalangan da'i. Namun, tidak semua sistem dakwah daring dapat dilaksanakan mengingat di beberapa wilayah di Indonesia masih banyak yang awam dengan teknologi. Akan tetapi adanya pandemi saat ini menuntut beberapa sektor, -terutama sektor keagaamaanuntuk menggunakan teknologi guna mempermudah aktivitas mereka. Untuk itu, demi kelancaran dalam berdakwah pihak LDNU Yogyakarta mencoba memanfaatkan teknologi dan media sosial untuk tetap eksis dalam berdakwah.

Pada masa observasi, peneliti menemukan beberapa strategi dakwah yang 
digunakan LDNU Yogyakarta demi tetap eksis di tengah masa pandemi saat ini, misalnya saja siaran radio by phone, mengadakan beberapa webinar, live streaming di youtube, dan ngaji online yang disiarkan langsung di live instagram dan facebook. Penggunaan media tersebut dilakukan secara fluktuatif. Artinya, pihak LDNU Yogyakarta akan terus berinovasi serta melakukan evaluasi secara kontinu demi menciptakan dakwah digital yang efektif dan efisien

Sebelum membahas lebih lanjut, perlu diketahui bahwa dalam lingkup ilmu dakwah tidak dikenalkan secara spesifik mengenai apa itu media dakwah. Namun, ketika memasuki era new media keberadaan media sebagai sarana berdakwah mulai dikenalkan dan dikaji lebih dalam. Lebih jelasnya lagi berikut beberapa pengertian mengenai media dakwah:

1. Media dakwah adalah instrumen yang digunakan untuk menyampaikan pesan atau saluran pembawa pesan yang menghubungkan antara da'I dan audiens (Sambas, 2004).

2. Media dakwah adalah alat yang digunakan untuk menyampaikan pesan berupa materi dakwah (ajaran Islam) kepada audiens(Munir, 2006)

3. Media dakwah dapat dimaknai sebagai alat atau sarana yang digunakan dalam berdakwah dengan harapan dapat mempermudah penyampaian pesan kepada audiens(Fauziyah, 2006)

Berdasarkan definisi-definisi tersebut, maka pengertian media dakwah dapat disimpulkan sebagai alat yang digunakan sebagai penyampaian pesan dakwah kepada audiens dengan harapan pesan yang disampaikan dapat diterima dengan baik. Dengan demikian media dakwah dapat dikelompokkan menjadi tiga, yakni; media auditif (radio, tape recorder), media visual (majalah, surat, poster, buku, brosur, dan lainlain), media audio visual (televisi, film, sinetron, dan lain-lain) (Aziz, 2015).Dari ketiga kelompok tersebut tentunya da'I memiliki banyak pilihan dalam menggunakan media dalam berdakwah. Sekalipun media bukan menjadi faktor utama kefektifan dalam berdakwah, namun secara implisit pemilihan media yang tepat dapat menciptakan kesuksesan dalam berdakwah. Oleh karena itu penting bagi seorang da'I selektif dalam menentukan media mana yang akan digunakan dalam berdakwah.

Pada dasarnya media dapat berperan efektif jika media tersebut sesuai dengan karakteristik, baik pendakwah (da'i), pesan dakwah dan audiens atau mitra dakwah (mad'u). selain ketiga karakteristik tersebut media juga harus menyesuaikan diri pada metode dakwah yang digunakan dan logistik. Kesimpulannya, media dakwah sangat terkait dengan kondisi unsur-unsur dalam berdakwah (Aziz, 2015).

Oleh karena itu dalam pemilihan media dakwah seorang da'I harus menekankan pada tiga hal; Pertama, da'I harus mengetahui karakteristik dari media yang digunakan. Misalnya ketika seorang da'I ingin menjelaskan tentang pesan kiamat tentunya penggunaan media audio visual lebih menarik dibandingkan dengan media audio. Sebab, dengan penggunaan media audio visual pesan 
tentang hari kiamat akan lebih mengena dikarenakan mad'u diajak untuk berimajinasi mengenai betapa mengerikannya ketika hari kiamat itu tiba. Kedua, pendakwah harus memahami dan memperhatikan kondisi audiens. Maksudnya, seorang da'I harus faham betul kepada siapa pesan dakwahnya akan disampaikan dengan demikian pesan yang ingin disampaikan lebih dapat diterima, sebagai contohnya; seorang da'I akan melakukan ceramah terkait maulid nabi Muhammad SAW dengan sasaran audiensnya adalah anak-anak sekolah dasar. Dalam hal ini penggunaan media film animasi akan lebih mengena dibandingkan dengan audio saja. Dan yang terakhir adalah etika. Maksudnya, media dakwah dapat menurunkan kualitas dakwah bila media tersebut melanggar etika, contohnya berdakwah melalui film religi. Kualitas serta etika sebuah film religi dapat dilihat dari isi pesan dan aktor atau artis dalam film tersebut. Jika film religi menggunakan aktor yang memiliki catatan hitam di industri perfilman tentu hal ini dapat mempengaruhi nilai atau etika dari film religi tersebut. Untuk itu sangat penting sekali melakukan seleksi ketat, tidak hanya terkait kualitas akting saja namun juga terkait latar kehidupan sosial aktor atau artis tersebut.

Lalu bagaimana dengan media dakwah LDNU Yogyakarta? Seperti yang dijelaskan sebelumnya bahwa berbagai macam media terutama media sosial- digunakan untuk kelancaran dalam berdakwah selama pandemi berlangsung. Adapun media yang lebih banyak digunakan oleh LDNU Yogyakarta dalam berdakwah selama pandemi berlangsung adalah media Youtube. Pihak LDNU Yogyakarta bekerjasama dengan Bangkit TV, NU Care, LAZIZNU DIY, dan UMMA Indonesia mengadakan kegiatan ngaji online dengan menggandeng beberapa tokoh agama yang tersohor di Yogyakarta.

Tidak hanya itu saja, beberapa pengurus LDNU Yogyakarta juga ikut terlibat dalam mengisi kajian rutinan. Namun, yang menjadi pembeda adalah pengurus LDNU Yogyakarta lebih memfokuskan dakwah melalui radio RRI. Akan tetapi semenjak diberlakukan sistem work from home (WFH), maka dakwah melalui radio dilakukan secara langsung by phone. Artinya, pihak Radio, baik RRI Pro 1 maupun RRI Pro 2 akan menghubungi narasumber melalui telephone secara langsung setiap hari rabu jam lima sore.

Lebih lanjut lagi, LDNU Yogyakarta melalui akun instagram resminya @ldnu_yogyakarta juga turut menyiarkan kajian rutinan yang diselenggarakan secara live dengan jadwal tentatif. Untuk pengisi kajian pun dilakukan secara random. Hal ini dilakukan mengingat masih menyesuaikan kebiasaan dan aktifitas baru para pengurus LDNU Yogyakarta selama pandemi berlangsung.

\subsection{Peluang dan Tantangan}

Pada hakekatnya, media memiliki kekuasaan penuh terhadap segala bentuk perubahan. Dalam hal ini, media -terutama media digital- telah berperan secara signifikan dalam memobilisasi masyarakat untuk melakukan beberapa perubahan (Sujoko, 2019).Besarnya kekuatan media dalam 
memberikan pengaruh terhadap audiens seringkali dimanfaatkan oleh masyarakat dari berbagai kalangan untuk memenuhi hasrat dan kepentingan mereka seperti halnya yang dilakukan oleh LDNU Yogyakarta.

Selama masa pandemi, berbagai upaya dilakukan oleh LDNU Yogyakarta untuk tetap eksis dalam berdakwah. Oleh sebab itu, berbagai media dakwah digunakan guna mencari dan menyeleksi media mana yang memiliki pengaruh cukup besar di masyarakat. Sejauh ini, media -terutama yang berbasis internet- seringkali menjadi rujukan atau referensi bagi generasi milenial. Sebab, media berbasis internet dinilai dapat mempengaruhi sikap, pandangan, perilaku bahkan pemahaman terhadap agama (Syahputra, 2019).

Fakta terkait fenomena kekuatan media inilah yang dijadikan landasan bagi LDNU Yogyakarta untuk memanfaatkan media berbasis internet agar tetap eksis dalam berdakwah. Akan tetapi, besarnya pengaruh dari kekuatan media ini tidak selamanya memberikan dampak positif. Seperti yang kita ketahui bahwa penggunaan internet sampai saat ini terus mengalami peningkatan. Menurut lembaga survey internasional, statista Global Consumer Survey (2019), penggunaan internet selama 2019 mencapai 3,9 milyar dalam skala dunia dari jumlah penduduk dunia sekitar 8,5 milyar jiwa, jadi bisa disimpulkan bahwa hampir setengah jumlah penduduk dunia menggunakan internet (Anshar, 2019).

Besarnya jumlah pengguna internet ini tidak lepas dari tingginya pengguna situs jejaring sosial atau media sosial. Beragamnya media sosial saat ini menjadi daya tarik bagi masyarakat yang ingin selalu eksis di ruang publik. Media sosial seakan memberi segala kebutuhan masyarakat dalam bersosial dan hal tersebut dikarenakan lengkapnya fitur-fitur yang mereka tawarkan. Namun, kelengkapan tersebut bisa juga menjadi boomerang bagi masyarakat yang belum siap akan perubahan. Umumnya, mereka -yang tidak siap akan perubahan- akan mengalami kendala ketika mendapatkan gempuran informasi dari berbagai sudut. Dan gempuran tersebut akan menjadi masalah baru jika si pengguna tidak cukup wawasan untuk memfilter informasi tersebut.

Dengan demikian dapat disimpulkan media sosial memilliki keseimbangan antara kelebihan dengan kekurangannya. Dalam hal ini LDNU Yogyakarta mencoba memanfaatkan kelebihan tersebut dan meminilimasir kekurangannya, yakni melalui evaluasi secara berkala. Adapun evaluasi tersebut dilakukan secara kondisional, artinya bisa dilakukan melalui diskusi tidak terjadwal, baik secara daring maupun secara luring. Sebab, sebagaian dari pengurus LDNU Yogyakarta memiliki aktifitas lain di luar terdiri dari berbagai profesi misalnya, pengusaha, dosen, guru, mahasiswa, karyawan negeri maupun swasta, dan lain-lain.

Berdasarkan kondisi yang tengah dialami oleh LDNU Yogyakarta ini menunjukkan bahwa adanya keselarasan dengan model komunikasi yang ditawarkan oleh Lassweell. Model komunikasi Lasswell ini menjelaskan bahwa adanya kompleksitas dalam proses komunikasi, yakni mengenai 
Who Says What In Which Channel To Whom With What Effect?. Meski model komunikasi ini menjelaskan linearitas proses komunikasi, namun model ini juga menunjukkan bahwa efektifitas sebuah komunikasi harus didukung dengan kestabilan komponen komunikasi. Artinya, model ini sangat sesuai menggambarkan bentuk komunikasi massa yang mana minim feedback. Jadi, dalam hal ini komunikator, pesan, media, komunikan harus berjalan seirama demi menciptakan efek yang sesuai dengan ekspetasi komunikator.

Pada studi kasus LDNU Yogyakarta pun juga sama, yakni demi menjaga eksistensi di tengah pandemi covid-19 ini dibutuhkan keselarasan antara LDNU Yogyakarta, pesan, dan media yang digunakan selama pandemi saat ini. Sebab, seperti yang dijelaskan sebelumnya bahwa di beberapa kesempatan LDNU Yogyakarta mengalami permasalahan, baik dalam pemilihan media maupun dengan optimalisasi media dakwah. Sehingga di beberapa waktu LDNU Yogyakarta mengalami kesulitan dan kurang optimal dalam melakukan dakwah melalui media daring. Namun, di sisi lain pihak LDNU Yogyakarta mencoba mengoptimalkan melalui evaluasi yang dilakukan secara tentatif demi memaksimalkan dakwah di tengah pandemi covid-19.

\section{Simpulan}

Selama masa pandemi, Lembaga

Dakwah Nahdhotul Ulama (LDNU)

Yogyakarta berusaha untuk tetap eksis dalam kegiatan dakwahnya. Hal ini dibuktikan dengan berbagai upaya yang telah dilakukan oleh LDNU Yogyakarta dalam mengubah pola dakwah yang selama ini mengandalkan fisik (off air) ke dakwah daring (online), baik program-program yang terjadwal maupun yang aksidental. Beberapa program yang mengalami penyesuaian selama pandemi adalah dakwah melalui radio, RRI Pro 1 dan Pro 2, yang dilakukan secara langsung by phone serta kajian rutinan LDNU Yogyakarta melalui akun resminya, baik Instagram, Facebook, maupun Youtube secara live dengan jadwal tentatif.

Dalam melaksanakan dakwah secara daring selama masa pandemi ini, LDNU Yogyakarta cukup berani melakukan terobosan dengan perubahan pola dakwah tersebut, terutama dengan menggunakan teknologi. Hal ini cukup menantang sebab para da'i tidak hanya dituntut untuk untuk menguasai teknologi dalam waktu singkat, namun juga tetap menjaga mutu isi dakwah agar sampai pada masyarakat. Selain itu, LDNU Yogyakarta juga secara periodik melakukan evaluasi terkait pembaharuan program dakwah tersebut. Hal ini juga menjadi poin tersendiri bagi LDNU Yogyakarta dalam menjaga eksistensi dakwahnya di masa pandemi ini.

\section{Daftar Pustaka}

Arsip LDNU Yogyakarta

Anshar, Muhammad. 2019.Dakwah Multimedia di Situs Jejaring Sosial Facebook. JKI: Jurnal Komunikasi Islam UIN Sunan Ampel Surabaya Vol 09 No 02.

DOI: https://doi.org/10.15642/jki.2019.9.2.213237. Diakses tanggal 12 Juni 2021.

Aziz, Ali. 2004. Ilmu Dakwah. Jakarta: Prenadamedia Group. 
Barowi dan Suwandi. 2008. Memahami Penelitian Kualitatif. Jakarta: Rineka Cipta.

Fauziyah, Mira. 2006. "Urgensi Media dalam Dakwah" dalam M Ja'far Puteh (ed.) Dakwah Tekstual dan Kontekstual. Yogyakarta: AK Group.

Ilaihi, W. 2010. Komunikasi Dakwah. Bandung: Remaja Rosdakarya.

Munir M dan Wahyu Ilahi. 2006, Manajemen Dakwah, Jakarta: Kencana.

Rahmad, Nur. 2018. Rekonstruksi Dakwahtainmen Sebagai Media Dakwah. Jurnal Dakwah. Vol 19 No 2. DOI: https://doi.org/10.14421/jd.2018.19201.

Diakses tanggal 12 Juni 2021.

Rohim, Syaiful. 2009. Teori komunikasi Perspektif: Ragam dan Aplikasi. Jakarta: Rineka Cipta.

Sambas, Sukriyadi, 2004. "Pokok-pokok Wilayah Kajian Ilmu Dakwah" dalam Ilmu Dakwah Kajian Berbagai Aspek. Aep Kusnawan (ed.), Bandung: Pustaka Bani Quraisy.

Septhiani, Revina. 2018. Strategi Dakwah Badan Musyawarah Organisasi Islam Wanita Indonesia (BMOIWI) Dalam Pembinaan Akhlak Muslimah di Majid Istiqlal,Skripsi, UIN Syarif Hidayatullah Jakarta.

Sirajuddin, Muniarty. 2014. Pengembangan Strategi Dakwah Melalui Media Internet (Peluang dan Tantangan). Al Irsyad al Nafs: Jurnal Bimbingan dan Penyuluhan Islam UIN Alauddin Makasar Vol 1 No 1.

Sugiono. 2012. Metode Penelitian Kuantitatif kualitatif dan $R \& D$. Bandung: Alfabeta

Syahputra , Iswandi. 2019. Media Relations Teori, Strategi, Praktik dan Media Intelijen. Depok: Rajawali Press

Pardianto. 2013. Meneguhkan Dakwah Melalui New Media. Jurnal Komunikasi Islam UIN Sunan Ampel SurabayaVol. 3, No. $1 . \quad$ DOI: https://doi.org/10.15642/jki.2013.3.1.\%25 p. diakses tanggal 12 Juni 2021. 